\title{
СУЧАСНИЙ ЕРГОНІМІКОН КАВ’ЯРЕНЬ МІСТА ХАРКОВА
}

Стаття присвячена розгляду ергонімів-неологізмів, що з 'являються як лінгвокультурні реалї в сучасному урбанізованому середовищі. Досліджено семантичні, структурні та графічні особливості ергонімів міста Харкова, а саме назв кав'ярень. Корпус мовних одиниць, використаних для дослідження, становить 84 одиниці. Виявлено причини, способи й засоби творення ергонімів. Підтверджено, що процеси творення таких власних назв мають не тільки лінгвістичні чинники, але й загальнокультурні, що характеризують шляхи розвитку глобалізованого суспільства.

Ключові слова: онім, ергонім, лінгвокультурна реалія, ономастичний простір.

Krapivnyk G. O., Shpak Yu. O. Contemporary Ergonyms for Coffee Houses in Kharkiv. The article is devoted to the consideration of the phenomenon of ergonomic neologisms, which appear as linguistic and cultural realities in the modern urbanized environment. The semantic, structural and graphical features of Kharkiv urban ergonyms naming coffee houses are explored. The corpus of the linguistic units under study consists of 84 units. The causes, methods and means of building ergonomics are considered. It is confirmed that the processes of creating such proper names are not only linguistic factors, but also general-cultural, characterizing the ways of the globalized society development. The selection of ergonyms with the foreign language element(s) on the designation of coffee places in Kharkiv was analyzed with three criteria (structural, semantic and graphic). The result was the creation of a classification of these names, which can be used later for consideration ergonyms of other subclasses. According to the first criterion, all names of analyzed coffee houses were distributed fairly evenly on groups of one-, two-and multi-component linguistic units. By the second criterion, semantic, the classification was made by the associations causing the specified names. Thus, it has been found that the typical feature of the names of coffee houses is the direct appeal to the main product offered by such food establishments (the coffee group was 60 units out of 84). In addition, associations with pastry and bakery products, atmosphere and target audience are widespread. According to the third criterion, graphical, analyzed titles showed signs of doubt about determining their place in the Ukrainian language system (Latin writing, transcoding, and domination of non-assimilated vocabulary).

Key words: onym, ergonym, linguistic-cultural realities, onomastic space.

\section{Вступ}

Кожного дня в містах у галузі громадського харчування з'являються заклади різного спрямування, відкриття яких неможливе без називання, тобто утворення й уживання ергонімів. Актуальність дослідження зумовлена активною появою неологізмів, що спричинено продовженням розвитку економічних і суспільних відносин міжнародного рівня. Лінгвістична наука потребує вивчення семантичних та структурних механізмів створення назв, потреби бізнесу, маркетингу й індустрії культури - виявити найбільш продуктивні способи творення (власних) назв, що будуть привертати увагу реципієнтів.

Метою дослідження є лінгвокультурологічний аналіз ергонімів-назв кав’ярень, які містять у своїй структурі іншомовний компонент. Завдання цієї розвідки передбачають виявлення причин активної появи вказаних ергонімів, характеристику структурних, семантичних і графічних особливостей зазначеної групи назв. 
Об'єктом дослідження є причини й засоби появи нових власних назв у сучасній мові. Предметом цієї розвідки є лінгвокультурні та структурносемантичні ознаки ергонімів-назв кав'ярень з іншомовним компонентом.

\section{Методи та методики дослідження}

Для проведення дослідження були використані такі наукові методи, як метод суцільної вибірки для отримання корпусу одиниць, що відповідають певним характеристикам; порівняльний (для проведення порівняльного аналізу ергонімів на лексичному рівні й виявлення подібності або відмінності в межах обраної групи мовних одиниць); асоціативний аналіз (метод асоціацій - для створення класифікаціі); структурно-семантичний метод та елементи кількісного аналізу (для виявлення основних структурно- семантичних типів ергонімів).

\section{Результати дискусії}

Ономастичний простір, що охоплює систему імен реальних і гіпотетичних об’єктів, визначається картиною світу, що існує наразі в кожного етносу. За словами О.В. Суперанської (1973), цей простір заповнюють найменування предметів, що належать до різних класів лексичної системи мови. Проблема системності кожної категорії ономастичної лексики може розв'язуватися своїм особливим способом.

Серед багатьох видів власних назв особливе місце займають так звані ергоніми, тобто власні назви підприємств, організацій, ділових і неділових об’єднань людей. Ця група онімів привертає увагу мовознавців і спеціалістів з інших галузей, наприклад, маркетингу або соціології. Термін ергонім використовують Ф. Алістанова, А. Беспалова, З. Бузинова, М. Голомидова, С. Земскова, Г. Зимовець, О. Мікіна, Н. Носенко, Н. Подольська, Т. Романова, О. Суперанська, М. Цілина, С. Шестакова, М. Шимкевич та ін. Разом із тим деякі дослідники пропонують й інші терміни на позначення реалій або явищ вторинної номінації. Наприклад, прагмонім - термін, що був запропонований 3. Комоловою, яка включила до цього розряду лексики назви товарів (Комолова, 1974), або трапезонім - назва об'єкта ресторанного бізнесу.

Ергоніми як соціально орієнтовані одиниці, що існують у лінгвокультурологічному й прагматичному аспектах, соціально й економічно детерміновані. Вивчення ергонімів як класу власних найменувань у східнослов'янському мовознавстві почалося ще в 60-70-х роках XX ст. у російській ономастиці в працях Б. Букчиної, І. Долгачова, Г. Золотової, М. Морозової, В. Ткачука. Більшу теоретичну значущість мали наукові праці О. Суперанської, яка визначила місце ергонімів у загальній класифікації онімів та їхні мотиваційні типи, і Л. Щетиніна, котрий з'ясував принципи номінації назв готелів, ресторанів, театрів, галерей.

Другий етап аналізу класу ергонімів розпочинається у $90-x$ роках минулого століття й відзначається продуктивністю у вивченні цих власних найменувань. Назви ділових об'єднань людей у функціональному аспекті розглядає В. Лейчик, принципи й способи номінації англійської ергонімії досліджує О. Беспалова. Водночас з'являються грунтовні наукові праці 
українських ономастів. Наприклад, типи мотивованості ергонімів м. Києва стають об'єктами вивчення Л. Соколової. Дисертаційна робота О. Мікіної була присвячена номінативним процесам у сучасній європейській ергоніміі. Назви комерційно-виробничих підприємств (фірмонімів) Закарпаття комплексно розглянув О. Белей.

На початку XXI ст. дослідження ергонімів не втрачає своєї актуальності в лінгвістиці, тому щорічно починають з'являтися наукові розвідки з вивчення виникнення та функціонування власних назв в окремих мовах: українській (М. Вінтонів, Ю. Карпенко), російській (О. Суперанська, В. Бондалєтов, В. Поротников), англійській (О. Леонович, А. Рибакін, А. Чигирьова), а також зіставні дослідження (В. Скляренко, О. Грінінгер).

У сучасному українському мовознавстві ергоніми досліджуються як 3 позиції семантики та структури (Н. Кутуза, Г. Зимовець та інші), так i прагматики (Ю. Горожанов, Н. Лєсовець та інші), але переважно ареально. Написано вже грунтовні розвідки на матеріалі онімів кількох українських регіонів та деяких міст. Так, О. Белей досліджував ергоніми Закарпаття (Белей, 1999), Н. Кутуза - Одеси (Кутуза, 2003), Н. Лєсовець - Луганська (Лєсовець, 2007), О. Сидоренко - Донеччини (Сидоренко, 2017), М. Цілина (Цілина, 2006), Ю. Дідур (Дідур, 2015) - Києва, С. Шестакова (Шестакова, 2002) - Києва, Львова, Полтави, Сум, Харкова, Ю. Деременда - Тернопілля (Деременда, 2011), Ю. Горожанов - Луцька (Горожанов, 2013), О. Дудка, В. Пономаренко - Харкова (Дудка, Пономаренко, 2014). Проблема передачі іншомовних слів та словосполучень при найменуванні об'єктів різних сфер діяльності також уже поставала в деяких наукових працях. Наприклад, особливості трансформації англійських назв в українську мову надані в працях I. Корунця (Корунець, 1993), О. Сидоренка.

У цій розвідці розглядаються лише сучасні ергоніми на позначення кав’ярень, що розташовані в межах міста Харкова й містять іншомовний компонент. Такий розгляд може стати частиною комплексного дослідження найменувань ділових об'єднань міста Харкова, у чому є очевидна потреба, оскільки значна кількість власних назв у зазначеному місті спричинила певні труднощі з їхнім упровадженням у широкий обіг, зокрема й лінгвістичних. Джерелами іншомовних запозичень в ергонімах Харкова, що аналізуються, $€$ англійська, італійська та данська мови.

У сучасних дослідженнях з ергоніміки вже розроблено багато різних класифікацій: з погляду мотиваційних установок (М. Курбанова), за ступенем точності вказівки на об'єкт, що називається (Т. Новожилова), за трьома категоріями - ступенем умотивованості, структурою номінації, «рівнем прозорості» (М. Новочихіна). Інформація, що передається ергонімами, може бути рекламною й раціональною або комбінованого типу. 3 метою реалізації рекламної функції номінатори використовують різноманітні засоби створення ергонімів: лексичні засоби інших мов, структурні, словотвірні й графічні засоби.

Зібрані для дослідження назви кав'ярень міста Харкова можна класифікувати за різними критеріями. У цій науковій розвідці такими критеріями 
стали: 1) структурний, 2) семантичний (асоціативні зв’язки), 3) графічний (тобто спосіб написання: кирилиця, латиниця, шрифти, регістр тощо).

Здійснений структурно-семантичний і графічний аналіз ергонімів (трапезонімів) дозволив виокремити групи назв, що були створені за певними моделями. Семантично ці групи мають ядра та периферію, де назви можуть мати спільні риси більше ніж однієї групи.

Так це стосується найбільшої за кількістю й різноманітною за структурним наповненням групи ергонімів - назв кав'ярень зі словом (або основою) coffee у своєму складі. Із 85 лексичних одиниць, що розглядаються в цій науковій розвідці, 60 належать до визначеної групи. Наявність указаного компонента в назві кав'ярні свідчить про свідому апеляцію адресантів до своєї аудиторії, про вказівку на мету відвідання такої торгівельної точки й на основний продукт, тобто каву, наявний у такому закладі громадського харчування. Як було зазначено, ця велика група ергонімів є гетерогенною за своїм складом.

Загалом за структурним критерієм 85 одиниць, що розглядаються, розподілилися таким чином: однокомпонентні (разом 26 одиниць), двокомпонентні (28 одиниці); багатокомпонентні назви (30 одиниць).

Кількісний аналіз показує відсутність певної прихильності до конкретної структурної форми ергоніма, хоча тенденція до створення дво- і багатокомпонентних назв (з уточненнями) чітко простежується на рівні групи назв, що містить слово соffeе як структурний елемент.

У свою чергу, очевидно, що однокомпонентні лексичні одиниці сформовані певним способом словотвору, де найбільш продуктивними виявилися афіксація, основоскладання і телескопічність (affixation, compounding and blending/telescoping). При цьому на письмі однокомпонентні назви, що аналізуються, не завжди пишуть разом (F.R.I.E.N.D.S, Franc.ua тошо).

Двокомпонентні ергоніми є номінативними словосполученнями й вирізняються тематично й за функцією, що, зокрема, виконує слово coffee або інша головна лексична одиниця в певній назві (атрибутив/означення або головний член словосполучення): Lviv Croissants, Sneaker Mate, Coffee Mall, Coffee Life, Saint Coffee тощо.

Багатокомпонентні назви є більш складними і можуть мати або не мати центральний елемент. Вони можуть характеризуватися семантичною єдністю (наприклад, Seven Coffee Seeds, Red Fox Coffee, Deep Forest Coffee) або складатися $з$ двох частин - головної та пояснювальної/дескриптора (наприклад, Two Hearts Coffee \& Clothes, Brewkibar - Coffee, brew, bakery, Monkey kava coffee to go). Незважаючи на те, що окреслені ергоніми не є усталеними виразами, при їхньому створенні були враховані (або з'явилися випадково) ознаки, типові для фразеологізмів, наприклад, рима, ритм і стилістичні засоби виразності (на кшталт алітерації, асонансу тощо): Cats \& Coffee, Milk \& Cookies, Блек \& Miлк, Coffee and Clothes, Co. Means Coffee, Seven Coffee Seeds. Узаємопроникнення елементів української та іншої(их) мов є проявом феномена мовної інтерференції. Досить велику кількість одиниць у цій групі займають координовані синтаксичні конструкції типу N \& N (загалом серед 
багатокомпонентніх ергонімів нашої вибірки таких налічується 10 одиниць). У своїй розвідці про ергоніми міста Луцька (Горожанов, 2013) Ю. Горожанов вказує на те, що серед виокремлених ним назв (275 одиниць) багатокомпонентною була тільки одна, тобто в Харківському регіоні спостерігається дещо інша тенденція серед назв кав'ярень, для яких більш характерно мати назву з декількох компонентів.

За семантичним критерієм усі трапезоніми можна розподілити за асоціативними зв'язками, оскільки апеляція до реципієнта є чи не найважливішим елементом іiї успіху, а також успіху підприємства, що за ним стоїть. Як було зазначено вище, найбільшу групу назв становлять ті, що містять лексему соffeе у своєму складі. За семантикою до цієї групи цілком можна віднести й такі ергоніми, що містять лексему, тісно пов'язану з англійським словом coffee (kawa, kava, kofe, koffee etc.), яка при цьому відрізняється графічно або за походженням слова. Кількісно домінантною також є група з компонентом coffee - 42 назви (Game of Coffee, Wake Up Coffee etc.), тоді як kava/kawa наявна в 6 аналізованих лексичних одиницях (Hygge Kava, Kokawa, Aroma Kava, Я kava), kofe - у 3 назвах (Kofe-chashka, Koffee art, Kofein), а група, шо містить інші варіанти назви продукту, налічує 4 одиниці (Kaffana, RoBOOSTa, Barcoff, Caffissimo).

Досить поширеним способом називання кав'ярень $є$ апеляція до тих продуктів, що можна придбати й скуштувати разом із кавою. Наприклад, виявлено групу ергонімів, які апелюють до кондитерських виробів. Цікаво те, що назви цих продуктів уводяться англійською мовою або способом транскодування: Lviv croissants (Львівські круасани), Coffee \& Waffles (Кава та Вафлі), Waffle time (Час вафлів), Biscotti (з італ. печиво), Jam \& Coffee (Джем і кава), Milk \& cookies (Молоко і печиво), Brownie (Брауні - вид популярного шоколадного м'якого печива), Bubble Waffle (Повітряні Вафлі), Sweet Story (Солодка історія - солодощі, як акомпанемент до кави); Sweeter (асоціація із словом sweetener, підсолоджувач, а також зі словом sweet (у формі компаратива); окрім того, Sweeter є омофоном до світер/sweater - предмета одягу, що широко використовується у повсякденному, або casual, стилі; Belgium Waffles Cafü (кав'ярня з бельгійськими вафлями), BrewkiBar coffee brew bakery (останнє слово означає 'випічка'); Baker 75 Street bakery \& coffee.

Серед проаналізованих назв-ергонімів $€$ й такі, що вимагають декількох кроків, оскільки створені з довгим асоціативним ланцюгом. Такі трапезоніми експліцитно не свідчать про те, що в місці, яке вони називають, можна випити кави, але викликають в уяві потенційного клієнта країни уявлення про окремі місця або продукти, пов'язані з кавою прямо або опосередковано: Franc.иа (Франція - Париж - кав’ярні); Lviv croissants (Львів, круасани - кава, кав'ярні); F.R.I.E.N.D.S. (назва американського телесеріалу, персонажі якого збиралися в кав'ярні, щоб поговорити про життєві проблеми); Fifties (кав'ярня в стилі американського ретро 50 -х років 20 -го століття, намагання створити атмосферу романтичної кав'ярні, про яку більшість 3 нас має уявлення переважно через американський кінематограф); Milk\&cookies (печиво, молоко $\rightarrow$ напої з цими виробами $\rightarrow$ кава $\rightarrow$ кав'ярня); Sante (слово 
романського походження - Італія/Франція - кава - кав'ярня); Amadeus (Амадей Моцарт - Відень - кава - кав'ярня), Leaflet - слово leaflet - «листочок» відсилає нас до природи, органіки, асоціація більше зі здоровим способом життя, ніж із кавою, але там можна випити кави й купити солодощі, які зроблено з органічних продуктів; Bricks - заклад, оформлений у стилі ньюйоркського лофту, де вагому роль відіграє цегла, звідси асоціація із швидким життям міста, де має бути затишний куточок для відпочинку, а відпочинок це кава-брейк, отже - кав'ярня; SQUEEZER - імовірно, походить від назви приладу, у якому заварюється, а потім проціджується кава.

Стосовно асоціативного зв'язку з кондитерськими виробами слід зауважити, що ця група включає й назви з компонентом coffee, оскільки останні можуть характеризуватися й одночасною апеляцію до кави й кондитерського виробу, як доповнення до неї. Загальна кількість таких одиниць склала 11.

Іще одна семантична група об'єднує назви, що мають подвійне призначення харчувально-торговельного закладу. У таких закладах можна випити не тільки кави, а й поїсти (іноді пропонують досить розлоге меню). Наприклад, Coffee Space: coffee and food (кава та їжа), E-COFFEE lounge, разом із кавою й тістечком також можна купити хлібні вироби: By the Way coffee \& bakery, Baker 75 Street bakery \& coffee, CheBakery; купити різні сорти кавових бобів та сумішей: Coffee DOOR Brew Bar + Coffeeshop, Kharakter.coffee (shop), Coffee Mall, BrewkiBar coffee brew bakery, Coffeeshop, E-COFFEE lounge; можна випити кави й замовити або купити одяг: Two hearts Coffee \& Clothes; можна відпочити й побавитися з кішками: Cats \& Coffee; почистити кросівки, поспілкуватися про нові релізи, дропи, подивитися й обговорити фільми про вуличну моду й снікер-культуру або просто насолодитися кавою, звареною зі свіжообсмаженої кави сорту «Арабіка» в кав'ярні Sneaker Mate. Подвійне (потрійне) призначення мають 13 назв із 85, що розглядаються в роботі.

Серед ергонімів Харкова можна виокремити й досить продуктивну модель називання кав'ярень, де є вказівка на людину, яка робить каву (Coffeebrewers, Bro Coffee Roasting), або на інші антропоніми, зооніми, топоніми: Amadeus (Амадей), Kraken Coffee co, Panda coffee, Cats \& Coffee, Monkey Kava coffee to go, Lviv croissants, Baker 75 Street (відома вулиця в Лондоні, на якій жив персонаж Конан-Дойла Шерлок Холмс), Barcoff - за формою нагадує прізвище в його англомовному варіанті, але утворене також з основи bar та усіченої основи слова coff(ee). Указівка на місце може бути здійснена й без залучення онімів, а тільки із зазначенням локалізації закладу: By the Way coffee \& bakery (де By the Way може мати два значення 1) по дорозі, 2) до речі, між іншим), Baker 75 Street (хоча не є реальною адресою), Underground Coffee (точки продажу дійсно знаходяться в переходах метро), Coffee-garage, Pitcher Loft Coffee, E-COFFEE lounge, Black forest Coffee, де слова garage, loft, lounge, forest називають не тільки місце, але й орієнтують на затишну атмосферу. Про атмосферу в різний спосіб говорять такі ергоніми, як F.R.I.E.N. 'D.S. (Дру3i), 2gether (together = разом), Coffee \& Break (Кава та Перерва), RelaxCoffee (Кава для відпочинку), Hygge kava («хюгге» - з данської мови, поняття, яке позначає затишок, комфортне спілкування), Coffee jeans $100 \%$ drive (drive $=$ 
активне бажання досягти мети, енергійні діï), Family coffee (Family = родина місце, де можна поспілкуватися як у родинному колі або з родиною), In the Mood - Take away coffee (In the Mood = y (гарному) настрої), Cats \& Coffee (Cats = коти, релакс, затишок); Magic cup coffee (Magic cup = чарівна чашка, що може означати «усе налагодиться після чашки нашої кави»). Ця семантична група є доволі гетерогенною й налічує разом 40 назв.

Досить часто назви кав'ярень указують на цільову аудиторію. Коли відкривається кав'ярня, то власники розуміють, що потрібно мати якусь відмінну рису або сфокусуватись на певних можливих клієнтах. Цей намір відображається часто і в назвах. Наприклад: F.R.I.E.N.D.S. (Друзі - місце, де ви можете зустрітися з друзями), My Coffee. Coffee for you (Моя кава, кава для тебе - роблю для кожної людини каву як для себе), Fashion coffee (модна кава - можливо, означає, що це модний заклад або тут можна спробувати модні кавові напої (гра слів, нагадує The Teddy Bear = Плюшевий ведмедик, кавабар для дівчат (стереотипне переконання про любов до м'яких іграшок), дітей або людей, які хочуть зануритися в атмосферу дитинства), 2gether (2gether $=$ together $=$ разом, для тих, хто хоче побути разом), Game of Coffee (авторська кав'ярня в стилі Game of Thrones, тому назва $€$ похідною від назви серіалу + продукт, для фанатів цього серіалу), Coffee \& Break (для тих, хто хоче зробити перерву в діяльності), Coffeeman (для фанатів кави), Family coffee (Family= родина, місце, де можна поспілкуватися як в родинному колі або прийти 3 родиною), Cats \& Coffee (для тих, хто любить котів), Sneaker Mate - «це хаб для всіх, хто цікавиться снікер- і вуличною культурою і справжніх кавоманів» (із сайту закладу, sneakers = кросівки). Серед проаналізованих ергонімів до цієї групи можна віднести 20 одиниць.

Переходячи до графічного критерію класифікації ергонімів-назв кав'ярень, зауважимо, що в цій роботі аналізуються тільки назви з іншомовним, частіше за все, англомовним компонентом (хоча в місті Харкові $\epsilon$, звичайно, й україномовні/російськомовні назви таких закладів: Перша Цукерня, Львівська майстерня шоколаду, Кав'ярня, Ідеальна чашка тощо). Тому $€$ значна специфіка й певні труднощі з визначенням місця таких назв у мові. За графічним критерієм нами виявлено такі варіанти графічного відтворення назв кав'ярень $з$ іншомовним компонентом:

1) створення назв з іншомовного (переважно англомовного) матеріалу і написання отриманих назв латиницею (Coffee Life, Coffee Room, Red Fox Coffee тощо);

2) транслітерація й транскодування з англійської на українську мову та навпаки - Блек \& Мiлк, з німецької на українську - Delikat (Делікат), Lviv Croissants, Zerno тощо;

3) гібриди: числа + букви, кирилиця + латиниця. 3 метою просування свого закладу, привертання уваги та сприянню запам'ятовування назви ергоніми можуть утворюватися шляхом транскодування (часткова або повна транслітерації з української на англійську мову, з іншої іноземної мови на українську) (Koffee-art, Delikat (Делікат) Coffeelaktika); складанням назви з літер кирилиці та латиниці (Я Каva (синтаксична омонімія); вживанням 
цифр у складі слів або замість слів (2gether, Baker 75 Street, Coffee jeans 100\% drive, 50 coffee); уживання інших символів у складі назви, переважно амперсанду (Jam \& Coffee, Up\&Go Coffee, Two hearts Coffee \& Clothes, Milk\&cookies, Coffee \& Break, By the Way coffee \& bakery, Cats \& Coffee).

Поява ергонімів у сучасному міському середовищі, зокрема міста Харкова, відбиває тенденції до створення так званих World Englishes, оскільки такі назви навряд можна назвати неологізмами української мови - вони частіше за все позначаються на письмі латиницею і тільки в деяких випадках мають українську транслітерацію, україномовну назву, повністю або частково (у словотворі). Процес дослідження продемонстрував наявність термінологічної дилеми - до чого відносити такі лексичні одиниці, їх часто можна віднести до варваризмів, неологізмів, оказіоналізмів. Із позицій традиційної лінгвістики складно знайти відповідь на це питання, але, з урахуванням постмодерністської парадигми відповідь існує - у площині інтердисциплінарності, колажності й взаємопроникнення різних галузей науки, різних культур і мов.

\section{Висновки}

Проведене дослідження дозволило зробити певні висновки. Вибірка ергонімів з іншомовним елементом(ами) на позначення кав'ярень у місті Харкові була проаналізована за трьома критеріями (структурним, семантичним і графічним). Результатом стало створення класифікації цих назв, яку можна застосовувати в подальшому для розгляду ергонімів інших підкласів. За першим критерієм усі назви кав'ярень, що аналізувалися, розподілилися досить рівномірно на групи одно-, дво- і багатокомпонентних мовних одиниць. За другим критерієм, семантичним, класифікацію було зроблено за асоціаціями, що викликають зазначені назви. Виявлено, що для назв кав'ярень типовою ознакою є застосування безпосередньої апеляції до основного продукту, який пропонується такими закладами харчування (група з компонентом coffee склала 60 одиниць із 85). Крім цього, поширеними $€$ асоціації з кондитерськими та хлібопекарськими продуктами, атмосферою та цільовою аудиторією. За третім критерієм, графічним, проаналізовані назви продемонстрували ознаки, що викликають сумніви щодо визначення їхнього місця в системі української мови (написання латиницею, транскодування й домінування неасимільованої лексики).

\section{ЛІТЕРАТУРА}

1. Белей О. О. Сучасна українська ергонімія: власні назви підприємств Закарпаття. Ужгород: [б.в.], 1999. 112 с. 2. Горожанов Ю. Ю. Ергоніми міста Луцька: структурно-семантичний аналіз. Філологічні студіï, 2013. Вип. 9. 3. Деременда Ю. М. Іншомовні засоби в ергонімії (на матеріалі ергонімікону Тернопілля). Філологічні трактати, 2011. Том 3, № 4. С. 107-114. 4. Дідур Ю. І. Особливості функціонування ергонімів у мові, мовленні та ментальному лексиконі (в українській, англійській та російській мовах): дис. ...канд. філол.наук: спец. 10.02.15. Одеса, 2015. 195 с. 5. Дудка О. О., Пономаренко В. Д. Сучасний ергонімікон Харкова: особливості структури і семантики. Науковий вісник кафедри ЮНЕСКО КНЛУ, серія Філологія, педагогіка, психологія, 2014. Випуск 28. 6. Лєсовець Н. М. Ергонімія м. Луганська: структурно-семантичний 
і соціально-функціональний аспекти: дис. ...канд. філол. наук: спец. 10.02.01. Луганськ, 2007. 295 с. 7. Комолова 3. П. Семантическая мотивированность прагмонимов. Проблемы семантики. Москва, 1974. С. 333-339. 8. Корунець І. В. Принципи і способи передачі українських особових і географічних назв англійською мовою. Мовознавство, 1993. № 3. С. 13-16. 9. Кутуза Н. В. Структурно-семантичні моделі ергонімів (на матеріалі ергонімікону Одеси): дис. ... канд. філ. наук: спец.10.02.01. Одеса, 2003. 214 с. 10. Сидоренко О. М. Іншомовний компонент в українських ергонімах (на прикладі назв готелів). НЗ ТНПУ. Сер: Мовознавство. 2017. 1(27). 11. Суперанская А. В. Общая теория имени собственного. Москва: Наука, 1973, 366 с. 12. Торчинський М. М. Структура онімного простору української мови. Частина II. Функціонування власних назв : монографія. Хмельницький : ХНУ, 2009.394 с. 13. Цілина М .М. Ергоніми м. Києва: структура, семантика, функціонування: дис. ...канд. філол. наук: спец. 10.02.01. Київ, 2006. 243 с. 14. Шестакова С. О. Лексико-семантичні інновації у системі сучасної української номінації (на матеріалі ергонімів і прагмонімів): дис. ... канд. філол. наук: спец. 10.02.01. Харків, 2002. 204 с.

\section{REFERENCES}

1. Beley, O. O. (1999). Suchasna ukrainska ergonimiia: vlasni nazvy pidpryiemstv Zakarpattia [Modern Ukrainian Ergonyms: Proper Names of Zakarpattia enterprises]. Uzhhorod [b.v.], (112 pp.) [in Ukrainian]. 2. Horozhanov, Yu. Yu. (2013). Erhonimy mista Lutsk: strukturno-semantychnyi analiz [Ergonyms of Lutsk: structural and semantic analysis]. Fililohichni studii. [Philological Studies]. Issue 9. 3. Deremenda, Yu. M. (2011). Inshomovni zasoby v erhonomii (na materiali erhonimikonu Ternopillia) [Foreign Language Means in Ergonymy]. Filolohichni traktaty. [Philological tractates] (Vol. 3), \# 4, 107-114 [in Ukrainian]. 4. Didur, Yu. I. (2015). Osoblyvosti funktsionuvonnia erhonimiv u movi, movlenni ta mentalnomu leksykoni (v ukrainskii, angliiskii ta rosiiskii movah) [Features of the ergonyms functioning in a language, speech and mental lexicon (in Ukrainian, English and Russian)]. Doctor's thesis, (195 pp.) [in Ukrainian]. 5. Dudka, O. O., Ponomarenko, V. D. (2014). Suchasnyi erhonimikon Kharkova: osoblyvosti struktury i semantyky [Modern ergonomys of Kharkiv: features of structure and semantics] Naukovyi visnyk kafedry UNESCO KNLU [Scientific bulletin of the KNLU UNESCO Chair], Series Philology, Pedagogics, Psychology, Issue 28 [in Ukrainian]. 6. Liesovets, N. M. (2007). Erhonimiia m. Luhanska: strukturno-semantychnyi i sotsialno-funktsionalnyi aspekty [Ergonyms of Luhansk: structural and semantic, social and functional analyses]. Doctor's thesis, (295 pp.) [in Ukrainian]. 7. Komolova, Z. P. (1974). Semanticheskaia motivirovannost pragmonimov [Semantic motivation of pragmonyms]. Problemy semantiki [Problems of Semantics]. M, 333-339 [in Russian]. 8. Korunets, I. V. (1993). Pryntsypy i sposoby peredachi ukrainskyh osobovyh i geografichnyh nazv angliyskoiu movoiu [Principles and methods for the transfer of Ukrainian personal and geographical names in English]. Movoznavstvo [Linguistics], (\# 3), 13-16 [in Ukrainian]. 9. Kutuza, N. V. (2003). Strukturno-semantychni modeli erhonimiv (na materiali erhonimikonu Odesy) [Structuralsemantic models of ergonomys (based on the ergonomys of Odesa)]. Doctor's thesis, (214 pp.) [in Ukrainian]. 10. Sydorenko, O. M. (2017). Inshomovnyi component v ukrainskyh erhonimah (na prykladi nazv hoteliv) [Foreign language component in Ukrainian ergonomys (hotel names)]. Ser. Movoznavstvo [Linguistics], 1(27), NZ TNPU [in Ukrainian]. 11. Superanskaia, A. V. (1973). Obshchaya teoriia imeni sobstvennogo [General theory of the proper name]. M: Nauka, (366 pp.) [in Russian]. 12. Torchynskyi, M. M. (2009). Struktura onimnoho prostoru ukrainskoi movy. Chastyna II. Funktsionuvannia vlasnyh nazv/The structure of the onymic space of the Ukrainian language. Part II Functioning of proper nouns]. Khmelnytskyi : KhNU, (394 pp.) [in Ukrainian]. 13. Tsilyna, M. M. (2006). Erhonimy m. Kyieva : struktura, semantyka, funktsionuvannia [Ergonoms of Kyiv: structure, semantics, functioning]. Doctor's thesis, 
(243 pp.) [in Ukrainian]. 14. Shestakova, S. O. (2002). Leksychno-semantychni innovatsii u systemi suchasnoi ukrainskoi nominatsii (na materiali erhonimiv i prahmonimiv) [Lexicosemantic innovations in the system of modern Ukrainian nomination (based on ergonomys and pragmonyms)]. Doctor's thesis, (204 pp.) [in Ukrainian].

Крапівник Ганна Олександрівна - доктор філософських наук, кандидат філологічних наук, доцент кафедри англійської філології, Харківський національний педагогічний університет імені Г. С. Сковороди; вул. Валентинівська, 2, Харків, 61168, Україна.

Тел.: +38-050-400-57-08

Email: Krap302@gmail.com

http://orcid.org/0000-0003-1641-987X

Krapivnyk Ganna Oleksandrivna - Doctor of Philosophy, $\mathrm{PhD}$ in Philology, Associate Professor, Department of English Philology, H.S. Skovoroda Kharkiv National Pedagogical University; Valentynivska Str., 2, Kharkiv, 61168, Ukraine.

Шиак Юлія Олександрівна - кандидат філологічних наук, доцент кафедри англійської філології, Харківський національний педагогічний університет імені Г. С. Сковороди; вул. Валентинівська, 2, Харків, 61168, Україна.

Тел.: +38-050-683-35-50

Email: starlingyu@gmail.com

http://orcid.org/0000-0001-5856-6945

Shpak Yuliia Oleksandrivna - PhD in Philology, Associate Professor, Department of English Philology, H.S. Skovoroda Kharkiv National Pedagogical University; Valentynivska Str., 2, Kharkiv, 61168, Ukraine.

Надійшла до редакції 01 березня 2019 року 